\title{
Increased excretion of soluble interleukin 2 receptors and free light chain immunoglobulins in the urine of patients with active lupus nephritis
}

\author{
Chang-Youh Tsai, Tsai-Hung Wu, Kuang-Hui Sun, Whu-Mei Lin, Chia-Li Yu
}

Section of Allergy, Immunology, and Rheumatology, Department of Medicine, Veterans General Hospital Taipei,

201 Section 2,

Shih-Pai Road,

Taipei,

Taiwan 11217,

Republic of China

C-Y Tsai

W-M Lin

C-L Yu

Section of Nephrology,

Department of Medicine,

Veterans General

Hospital Taipei,

201 Section 2,

Shih-Pai Road,

Taipei,

Taiwan 11217,

Republic of China

T-H Wu

School of

Medical Technology,

National Yang-Ming

Medical College,

201 Section 2,

Shih-Pai Road,

Taipei,

Taiwan 11217,

Republic of China

K-H Sun

Correspondence to:

Dr Chia-Li Yu.

Accepted for publication

18 March 1991

\begin{abstract}
Samples of protein from the urine of 23 patients with lupus nephropathy and 15 patients with proteinuria who did not have systemic lupus erythematosus (SLE) were studied for the presence of cytokines, soluble interleukin 2 receptors (sIL-2R), and free light chain immunoglobulins. The patients with lupus nephropathy were divided into two groups with active (nephritis) and inactive inflammation (nephrosis) based on the results of the analysis of urine samples and renal histology. The crude urine proteins $(5 \mathrm{mg} / \mathrm{ml})$ after precipitation by $80 \%$ ammonium sulphate from 14 patients with lupus nephritis contained higher concentrations of sIL-2R (4.88 (SEM $1.27 \mathrm{ng} / \mathrm{ml}$ ) than those from nine patients with nephrosis $(1.11(0.52) \mathrm{ng} / \mathrm{ml})$ or 15 patients without SLE $(1.31(0.87) \mathrm{ng} / \mathrm{ml})$. The concentration of sIL-2R in protein from urine samples was not correlated with the concentration in plasma and was inversely correlated with the excretion of protein in urine over 24 hours in patients with SLE. It is suggested that, in addition to leakage from the circulation, the local production of sIL-2R by inflamed kidneys is possible. The crude proteins in urine were further fractionated by gel filtration on Sephacryl S-200. Arbitrarily, four fractions could be obtained from urine from patients with SLE but only three fractions were found in the urine of patients without SLE. Fraction IV derived from patients with nephritis or nephrosis augmented the pokeweed mitogen induced $\left[{ }^{3} \mathbf{H}\right]$ thymidine uptake of mononuclear cells. In addition, the positive rates of free kappa $(x)(35.7 \%)$ and lambda $(\lambda)(42.9 \%)$ chains in proteins in urine from nephritic patients were higher than those in the other two groups. These results suggest that the severity of inflammation in the kidneys of patients with lupus can be reflected by the increased excretion of sIL-2R, free light chain immunoglobulins, and cytokine-like molecules in urine.
\end{abstract}

Lupus nephritis has long been regarded as a prototype of immune complex mediated inflammatory reactions. Many investigators ${ }^{1-3}$ have shown that the infiltrates of monocytes, $T$ and $B$ lymphocytes, and polymorphonuclear leucocytes in the glomeruli play an important role in murine and human glomerulonephritis. Cytokines and other inflammatory mediators secreted by these infiltrating mononuclear and mesangial cells ${ }^{4}$ are believed to initiate the inflammation and ultimately to lead to tissue necrosis of the kidney. Using Northern blot analysis, Boswell et al ${ }^{7}$ found that expression of tumour necrosis factor (TNF) and interleukin $1 \beta$ (IL-1 $\beta$ ) mRNA were enhanced in glomerular macrophages in the lupus prone (MRL/lpr) mouse during the course of the disease. Noble $e t a l^{8}$ found that the urinary excretion of cytokines, including IL-1 $\beta$ and TNF, might reflect the severity of renal inflammation in experimental immune complex induced glomerulonephritis. However, there are very few reports on the amount of cytokines in the proteins from urine of patients with lupus nephritis.

Hopper and Papagiannes 9 showed a significant amount of unbound polyclonal light chain immunoglobulins in the culture supernatant of mitogen stimulated normal human mononuclear cells. Epstein ${ }^{10}$ and Hopper et $a l^{11}$ further reported that clinical relapse of patients with systemic lupus erythematosus (SLE) was correlated with an antecedent increase in free light chain immunoglobulins in urine. The interrelation between the increased free light chains in urine and the severity of lupus nephritis in humans has not yet been clearly shown.

In this study, we compared the concentrations of cytokines, cytokine inhibitor (soluble interleukin 2 receptor (sIL-2R)), free light chain immunoglobulins and immunological activity of proteins in urine from patients with and without SLE to evaluate more precisely the severity of inflammation and to understand further the immunological changes in patients with lupus nephritis.

Patients and methods

PATIENTS AND CONTROLS

Twenty three urine samples from patients fulfilling the 1982 revised criteria of the American Rheumatism Association for the classification of SLE were studied. These patients (19 women and four men with a mean age of 31.7 (SEM $11 \cdot 4)$ years) were further divided into two groups according to the results of urine analysis and renal histology. Fourteen patients were classified as having active lupus nephritis (nephritis group) owing to significantly increased white and red blood cell counts, casts in the urinary sediments and hypercellularity with mononuclear cell infiltration in the glomeruli. Nine patients were classified as having inactive lupus nephritis (nephrosis group) with the presence of normal urinary sediments and normocellularity with scanty mononuclear cell infiltration in the renal glomeruli. Fifteen 
patients without SLE with proteinuria (five with diabetic nephropathy, four with hypertensive nephrosclerosis, three with idiopathic membranous glomerulonephritis, and three with minimal nephrotic syndrome) served as controls. Urine was collected throughout a 24 hour period in the presence of $0.01 \%$ sodium azide as a preservative.

\section{COLLECTION OF URINE PROTEIN}

The urine sample was initially precipitated with $80 \%$ ammonium sulphate followed by centrifugation at $10000 \mathrm{~g}$ for 30 minutes. ${ }^{12} 13$ The pellet was constituted with $50 \mathrm{mM}$ TRIS buffer in $100 \mathrm{mM} \mathrm{NaCl}, \mathrm{pH} \mathrm{7.5}$. The solution was then intensively dialysed against at least 100 volumes of the same buffer for 48 hours with several changes. After dialysis, the protein solution was centrifuged at $300 \mathrm{~g}$ for 10 minutes and the clear supernatant (crude urine protein) was collected. The concentration of the crude urine protein was determined by the Bio-Rad protein assay kit (Bio-Rad Laboratories, Richmond, CA, USA). For further purification, the crude urine protein was fractionated by eluting with $0.15 \mathrm{M}$ TRIS buffer ( $\mathrm{pH} \mathrm{7.5)}$ through an $80 \times 2.5 \mathrm{~cm}$ Sephacryl S-200 gel filtration column at a flow rate of $20 \mathrm{ml} /$ hour. Four millilitres of eluent were collected in each tube. The different fractions were pooled, dialysed and concentrated.

DETERMINATION OF SIL-2R, TNF- $\alpha$ AND IL-6 IN CRUDE PROTEINS FROM URINE

Commercially available enzyme linked immunosorbent assay (ELISA) kits were used for the detection of sIL-2R (AMAC, Westbrook, Maine, USA), TNF- $\alpha$ (T cell $\cdot$ Sciences, Cambridge, MA, USA) and IL-6 (Genzyme, Boston, MA, USA). The detailed procedures are described by the manufacturers. Concentrations of TNF- $\alpha$ and IL- 6 higher than $4.8 \mathrm{pg} / \mathrm{ml}$ or $0.16 \mathrm{ng} / \mathrm{ml}$, respectively, in $5 \mathrm{mg} / \mathrm{ml}$ protein from urine were considered positive in this study.

QUANTITATION OF FREE KAPPA AND LAMBDA LIGHT CHAIN IMMUNOGLOBULINS IN CRUDE PROTEIN FROM URINE

As free light chain specific antisera were not available, urinary free light chain immunoglobulin was determined indirectly by calculation. The concentrations of $\operatorname{IgG}, \operatorname{IgA}, \operatorname{IgM}$, and total light chains in crude protein in urine $(5 \mathrm{mg} / \mathrm{ml})$ were measured by laser nephelometry (HoechstBehringwerke, Marburg, Germany). The free kappa $(x)$ and lambda $(\lambda)$ light chain immunoglobulins were then calculated according to the following equations: (A) total $\operatorname{Ig}(\mathrm{mg} / \mathrm{l})=\mathrm{IgG}+$ IgA+IgM; (B) calculated bound $x$ chain $=$ total Ig $\times 2 / 3$, calculated bound $\lambda$ chain $=$ total Ig $\times 1 / 3$; (C) free light chains, free $x$ chain= (measured $x$-calculated bound $x$ ) $\times 1 / 6$ (or $17 \%)$, free $\lambda$ chain $=($ measured $\lambda$-calculated bound $\lambda$ ) $\times 1 / 6$ (or $17 \%$ ).

\section{DETERMINATION OF POKEWEED MITOGEN} ENHANCING ACTIVITY OF PROTEIN IN URINE ON NORMAL MONONUCLEAR CELLS

Mononuclear cells were isolated from heparinised venous blood after centrifugation at $300 \mathrm{~g}$ for 30 minutes in a Ficoll-Hypaque density gradient (specific gravity 1.077). One hundred microlitres of mononuclear cells $\left(1 \times 10^{6} / \mathrm{ml}\right)$ were placed in flat bottomed microwells in triplicate. Twenty microlitres of pokeweed mitogen $(100 \mu \mathrm{g} / \mathrm{ml})$, $40 \mu \mathrm{l}$ of various fractions of urine protein $(0 \cdot 2$ $\mathrm{mg} / \mathrm{ml})$, human IgG $(0.2 \mathrm{mg} / \mathrm{ml})$, or RPMI 1640 medium, and $40 \mu \mathrm{l}$ of $10 \%$ fetal bovine serum in RPMI medium were added to the wells to give a total volume of $200 \mu \mathrm{l}$ in each well. The mixtures were incubated at $37^{\circ} \mathrm{C}$ in $5 \%$ carbon dioxide $/ 95 \%$ air for 68 hours. The cells were then pulsed with $18.5 \mathrm{kBq}$ methyl $\left[{ }^{3} \mathrm{H}\right]$ thymidine (specific activity $248 \mathrm{G} \mathrm{Bq} / \mathrm{mmol}$; NEN, Boston) per well for four hours. The cells were harvested and the radioactivity was measured by a beta counter. The percentage of pokeweed mitogen (PWM) enhancement was calculated by the following formula using the counts per minute (cpm):

$\begin{aligned} & \text { \%PWM enhancing } \\ & \text { activity }\end{aligned}=\left(\frac{\text { cpm with samples }- \text { cpm with medium }}{\text { cpm with medium }}\right) \times 100$

ELECTROPHORETIC ANALYSIS OF CRUDE PROTEINS FROM URINE AND THEIR ELUTION FRACTIONS

Ten microlitres of various samples of protein from urine (protein concentration $2 \mathrm{mg} / \mathrm{ml}$ )

Table 1 Clinical, laboratory, and renal histological findings in patients with active lupus nephritis

\begin{tabular}{|c|c|c|c|c|c|c|c|c|c|c|}
\hline \multirow{2}{*}{$\begin{array}{l}\text { Patient } \\
\text { No }\end{array}$} & \multirow[t]{2}{*}{ Sexi } & \multirow{2}{*}{$\begin{array}{l}\text { Age } \\
\text { (years) }\end{array}$} & \multirow{2}{*}{$\begin{array}{l}24 \text { Hour } \\
\text { urine protein } \\
\text { excretion }(g)\end{array}$} & \multicolumn{3}{|c|}{ Urinary sediments (/HPF) } & \multirow{2}{*}{$\begin{array}{l}\text { Renal } \\
\text { pathology* }\end{array}$} & \multirow{2}{*}{$\begin{array}{l}C 3 c \\
(m g / l)\end{array}$} & \multirow{2}{*}{$\begin{array}{l}C 4 \\
(m g / l)\end{array}$} & \multirow{2}{*}{$\begin{array}{l}\text { Antibody to } \\
\text { dsDNA } \\
(I U / m l)\end{array}$} \\
\hline & & & & $\begin{array}{l}\text { Red blood } \\
\text { cells }(n)\end{array}$ & $\begin{array}{l}\text { White blood } \\
\text { cells }(n)\end{array}$ & Casts & & & & \\
\hline $\begin{array}{l}1 \\
2 \\
3 \\
4 \\
5 \\
6 \\
7 \\
8\end{array}$ & $\begin{array}{l}M \\
F \\
F \\
F \\
F \\
F \\
F \\
F\end{array}$ & $\begin{array}{l}39 \\
30 \\
42 \\
39 \\
24 \\
34 \\
16 \\
28\end{array}$ & $\begin{array}{c}0.74 \\
3 \cdot 1 \\
12 \cdot 0 \\
0.19 \\
0.25 \\
2.5 \\
8.64 \\
8.05\end{array}$ & $\begin{array}{c}6-8 \\
5-10 \\
0-4 \\
0-4 \\
10-15 \\
0-4 \\
20-40 \\
20-40\end{array}$ & $\begin{array}{r}10-15 \\
15-25 \\
5-10 \\
10-30 \\
20-35 \\
10-15 \\
10-20 \\
25-50\end{array}$ & $\begin{array}{l}\begin{array}{l}\text { Hyaline } \\
\text { Granular } \\
\text { Hyaline }\end{array} \\
\overline{\text { Granular }} \\
\overline{\text { Hyaline }} \\
\text { Hyaline, } \\
\text { granular }\end{array}$ & $\begin{array}{l}\text { IV } \\
\text { IV } \\
\text { III } \\
\text { II } \\
\text { IV } \\
\text { III } \\
\text { IV } \\
\text { IV }\end{array}$ & $\begin{array}{r}40 \\
279 \\
846 \\
837 \\
266 \\
830 \\
401 \\
135\end{array}$ & $\begin{array}{r}211 \\
76 \\
364 \\
328 \\
41 \\
309 \\
151 \\
48\end{array}$ & $\begin{array}{c}89 \cdot 4 \\
15 \cdot 8 \\
40 \cdot 5 \\
28 \cdot 6 \\
2100 \\
36 \cdot 7 \\
214 \\
962\end{array}$ \\
\hline $\begin{array}{r}9 \\
10 \\
11 \\
12 \\
13 \\
14\end{array}$ & $\begin{array}{l}\mathbf{F} \\
\mathbf{F} \\
\mathbf{F} \\
\mathbf{F} \\
\mathbf{M} \\
\mathbf{F}\end{array}$ & $\begin{array}{l}17 \\
45 \\
24 \\
38 \\
26 \\
24\end{array}$ & $\begin{array}{c}0.7 \\
1.15 \\
1.11 \\
0.33 \\
14.6 \\
0.86\end{array}$ & $\begin{array}{c}0-4 \\
5-10 \\
10-20 \\
15-25 \\
0-5 \\
5-8\end{array}$ & $\begin{array}{r}5-10 \\
5-10 \\
20-40 \\
15-30 \\
6-15 \\
10-35\end{array}$ & $\begin{array}{l}- \\
\overline{\text { Hyaline }} \\
\text { Hyaline } \\
\overline{\text { Granular }}\end{array}$ & $\begin{array}{l}\text { II } \\
\text { III } \\
\text { IV } \\
\text { III } \\
\text { II } \\
\text { IV }\end{array}$ & $\begin{array}{l}603 \\
597 \\
258 \\
304 \\
209 \\
409\end{array}$ & $\begin{array}{r}198 \\
218 \\
91 \\
98 \\
116 \\
105\end{array}$ & $\begin{array}{c}36 \cdot 0 \\
1259 \\
1054 \\
126 \\
1575 \\
326\end{array}$ \\
\hline
\end{tabular}

${ }^{*}$ According to the World Health Organisation classification of lupus nephritis. 
under denatured conditions were applied to $10 \%$ sodium dodecyl sulphate-polyacrylamide gel. The voltage was $100 \mathrm{mV}$ and the temperature $4^{\circ} \mathrm{C}$. The total electrophoresis time was two hours. After electrophoresis, the gel was stained with Coomassie brilliant blue.

\section{STATISTICAL ANALYSIS}

The results were represented as the mean (SEM) in the whole study. The statistical significance was assessed by the non-parametric Wilcoxon signed rank test or Fisher's exact test.

\section{Results}

DEMOGRAPHIC AND LABORATORY ASSESSMENT OF THE PATIENTS WITH SLE

Tables 1 and 2 show the clinical and laboratory data for the patients with lupus nephropathy. The inflammatory activity of the kidney was mainly judged by the urinary sediments and renal histology. The changes in the urine sediments and renal biopsy were more active in the nephritis group than those in the nephrosis group. However, the serum abnormalities were the same in the two groups. All of the patients in the nephrotic group showed hypercholesterolaemia $(>9.1 \mathrm{mmol} / \mathrm{l})$ and decreased serum albumin $(<30 \mathrm{~g} / \mathrm{l})$. In addition, the 24 hour excretion of urine protein in the nephritis group $(3.87(4.86) \mathrm{g})$ was less than that of the nephrosis group $(11.40(7 \cdot 67) \mathrm{g})$, but was not different from that of the group without SLE $(6.51(4.43) \mathrm{g})$. Two patients with positive antinuclear antibodies (1/160 diffuse and 1/320 diffuse) in serum and five patients with increased white blood cells ( $>$ five cells/high powered field) in the urine were also found in the group without SLE.

\section{SOLUBLE IL-2 RECEPTOR IN CRUDE PROTEINS} FROM URINE

The concentration of sIL-2R in crude proteins from urine $(5 \mathrm{mg} / \mathrm{ml})$ in the nephritis group $(4 \cdot 88(1 \cdot 27) \mathrm{ng} / \mathrm{ml})$ was significantly higher than in the nephrosis group $(1.11(0.52) \mathrm{ng} / \mathrm{ml})$ or the group without SLE $(1.31(0.87) \mathrm{ng} / \mathrm{ml})$ as determined by a commercial ELISA kit (fig 1). To determine if the high level of urinary sIL-2R in the nephritis group was due to local production by the inflamed kidney, we compared the concentrations of sIL-2R in plasma and urine in these patients, but no correlation could be found (data not shown). In addition, the sIL-2R concentration in protein from urine was inversely correlated with the 24 hour protein excretion in patients with SLE (fig 2). It appears that local production of sIL-2R in the active inflamed kidney is possible.

PRESENCE OF FREE LIGHT CHAIN IMMUNOGLOBULINS, TNF- $\alpha$ AND IL-6 IN CRUDE PROTEINS FROM URINE

Table 3 shows that the positive rate of free kappa $(35 \cdot 7 \%)$ and free lambda $(42 \cdot 9 \%)$ chains in proteins from nephritic urine $(5 \mathrm{mg} / \mathrm{ml})$ was significantly higher than that in the other two groups. As only a few samples of protein from

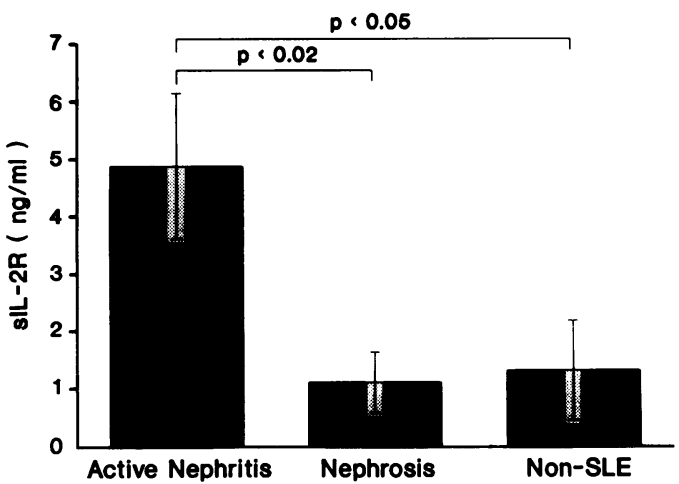

Figure 1 Comparison of soluble interleukin 2 receptor (sIL-2R) concentration in proteins from urine $(5 \mathrm{mg} / \mathrm{ml})$ of patients with active lupus nephritis, inactive lupus nephritis (nephrosis), and nephropathy without SLE (non-SLE).

Table 2 Clinical, laboratory and renal histological findings in patients with inactive lupus nephritis

\begin{tabular}{|c|c|c|c|c|c|c|c|c|c|c|}
\hline \multirow{2}{*}{$\begin{array}{l}\text { Patient } \\
\text { No }\end{array}$} & \multirow[t]{2}{*}{ Sex } & \multirow{2}{*}{$\begin{array}{l}\text { Age } \\
\text { (years) }\end{array}$} & \multirow{2}{*}{$\begin{array}{l}24 \text { Hour } \\
\text { urine protein } \\
\text { excretion }(\mathrm{g})\end{array}$} & \multicolumn{3}{|c|}{ Urinary sediments (/HPF) } & \multirow{2}{*}{$\begin{array}{l}\text { Renal } \\
\text { pathology" }\end{array}$} & \multirow{2}{*}{$\begin{array}{l}C 3 c \\
(m g / l)\end{array}$} & \multirow{2}{*}{$\begin{array}{l}C 4 \\
(m g / l)\end{array}$} & \multirow{2}{*}{$\begin{array}{l}\text { Antibody to } \\
\text { dsDNA } \\
(I U / m l)\end{array}$} \\
\hline & & & & $\begin{array}{l}R B C \\
(n)\end{array}$ & $\begin{array}{l}W B C \\
(n)\end{array}$ & Cast & & & & \\
\hline $\begin{array}{l}1 \\
2 \\
3 \\
4 \\
5 \\
6 \\
7 \\
8 \\
9\end{array}$ & $\begin{array}{l}F \\
F \\
F \\
M \\
F \\
F \\
F \\
F \\
M\end{array}$ & $\begin{array}{l}34 \\
24 \\
17 \\
64 \\
30 \\
42 \\
18 \\
43 \\
30\end{array}$ & $\begin{array}{c}8 \cdot 68 \\
7 \cdot 55 \\
7 \cdot 94 \\
25 \cdot 6 \\
10 \cdot 0 \\
8 \cdot 64 \\
7 \cdot 49 \\
23 \cdot 42 \\
3 \cdot 3\end{array}$ & $\begin{array}{l}0-2 \\
0-5 \\
0-5 \\
0-2 \\
1-5 \\
0-5 \\
0-3 \\
0-2 \\
0-2\end{array}$ & $\begin{array}{l}0-5 \\
0-5 \\
0-5 \\
0-2 \\
0-2 \\
0-5 \\
0-2 \\
0-3 \\
0-5\end{array}$ & $\begin{array}{l}- \\
\overline{-} \\
\text { Hyaline } \\
= \\
= \\
=\end{array}$ & $\begin{array}{l}\text { III } \\
\text { IV } \\
\text { IV } \\
\text { I } \\
\text { V } \\
\text { V } \\
\text { III } \\
\text { II } \\
\text { IV }\end{array}$ & $\begin{array}{l}398 \\
218 \\
198 \\
852 \\
158 \\
415 \\
319 \\
459 \\
923\end{array}$ & $\begin{array}{r}210 \\
172 \\
127 \\
654 \\
43 \\
157 \\
80 \\
140 \\
442\end{array}$ & $\begin{array}{c}17 \cdot 8 \\
105 \cdot 4 \\
215 \cdot 5 \\
<8 \\
48 \cdot 7 \\
36 \cdot 5 \\
63 \cdot 5 \\
44 \cdot 7 \\
<8\end{array}$ \\
\hline
\end{tabular}

*According to the WHO classification of lupus nephritis.

Table 3 Presence of free light chains, $T N F-\alpha$, and IL-6 in crude proteins in urine from patients with active and inactive lupus nephritis and nephropathy without SLE. Results are shown as number (percentage)

\begin{tabular}{lllll}
\hline Disease group & Free light chains & & $T N F-\alpha$ & $I L-6$ \\
\cline { 2 - 5 } & Kappa & Lambda & \\
\hline Active lupus nephritis & $5 / 14(36)$ & $6 / 14(43)$ & $2 / 14(14)$ & $3 / 14(21)$ \\
Inactive lupus nephritis & $0 / 9^{*}(0)$ & $0 / 9^{*}(0)$ & $1 / 9(11)$ & $1 / 9(11)$ \\
Wichout SLE & $0 / 15+(0)$ & $0 / 15+(0)$ & $0 / 15(0)$ & $0 / 15(0)$ \\
\hline
\end{tabular}

*Compared with patients with active lupus nephritis, $p=0.0036$ by Fisher's exact test.

tCompared with patients with active lupus nephritis, $p=0.0297$ by Fisher's exact test. 
urine contained TNF- $\alpha$ (two of 14 in the nephritis group, one of nine in the nephrosis group) and IL-6 (three of 14 in the nephritis group, one of nine in the nephrosis group), the differences among these three groups were not significant.

SEPHACRYL S-200 FRACTIONATION OF PROTEIN FROM URINE

Figure 3 shows a typical chromatogram for protein in urine from a patient with lupus nephritis (patient 14) after Sephacryl S-200 gel filtration. Arbitrarily, four fractions could be recognised in proteins from urine of nephritic or nephrotic patients, whereas only the first three fractions were seen in samples from patients without SLE. Fractions I, II, and III represent macromolecules (IgM and/or immune complexes), IgG, and albumin, respectively. Fraction IV is presumed to contain cytokines or

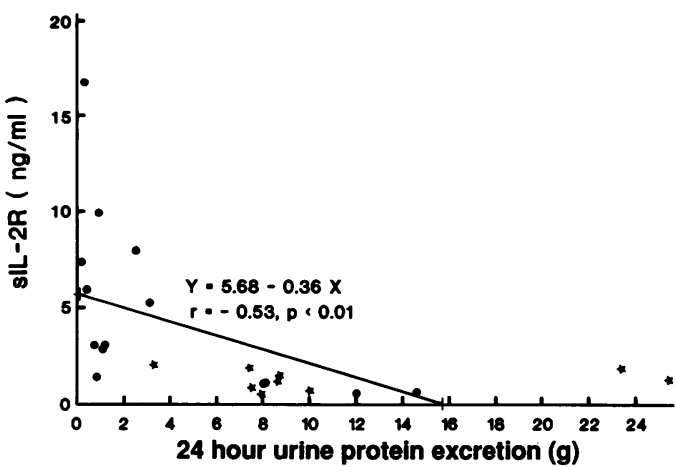

Figure 2 Correlation of soluble interleukin 2 receptor $(s I L-2 R)$ concentration and 24 hour urine protein excretion in patients with active $(O)$ and inactive $(\star)$ lupus nephritis.

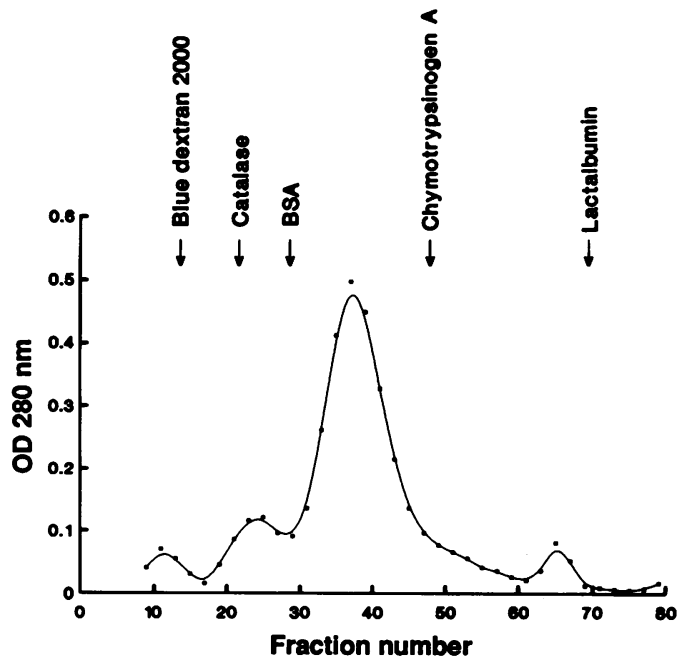

Figure 3 Typical chromatogram after Sephacryl S-200 gel filtration of protein in urine from the patient with active lupus nephritis (patient 14 in the nephritis group).

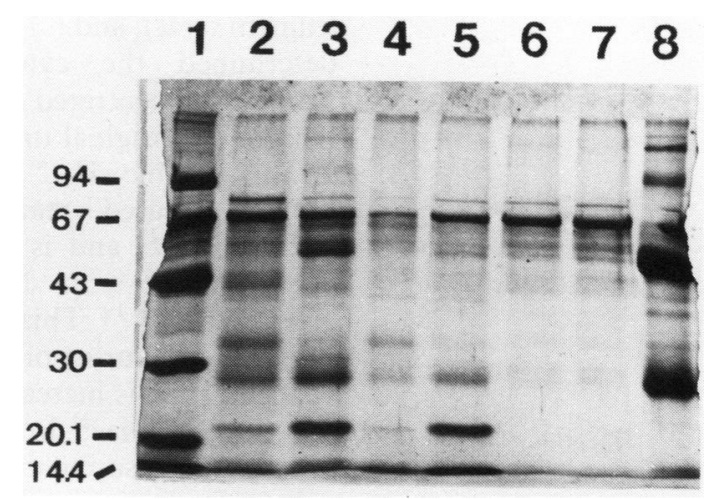

Figure 4 Electrophoretic analysis of crude proteins in urine and the fraction IV molecule from patients with active and inactive lupus nephritis using $10 \%$ sodium dodecyl sulphate-polyacrylamide gel elecytrophoresis. Lane 1 , calibration molecules; lane 2 fraction IV from patients with inactive nephritis (sample I); lane 3, fraction IV from patients with active nephritis (sample I); lane 4, fraction IV from patients with inactive nephritis (sample II); lane 5, fraction IV from patients with active nephritis (sample II), lane 6, crude proteins in urine from patients with active nephritis; lane 7, crude proteins in urine from patients with inactive nephritis; lane 8 normal human IgG.

cytokine related molecules. These fractions were pooled, dialysed and sterilised for determining the immunological activity. At a concentration of $40 \mu \mathrm{g} / \mathrm{ml}$, fraction IV from urine from the nephritic and nephrotic groups contained potent pokeweed mitogen enhancing activity on normal human mononuclear cells (table 4) but fractions I, II, and III were inactive. The estimated molecular weight of fraction IV determined under reducing condition by $10 \%$ sodium dodecyl sulphate-polyacrylamide gel electrophoresis was about 23 kilodaltons (fig 4).

\section{Discussion}

We analysed and compared the composition of proteins in urine from patients with and without SLE and found that increased sIL-2R and free light chain immunoglobulin concentrations in urine might reflect the severity of inflammation in the lupus kidney. Although certain cytokines such as IL-1, ${ }^{14}$ TNF, ${ }^{7}$ IL-6, ${ }^{15}$ and transforming growth factor $-\beta^{16}$ may play a role in the pathogenesis of glomerular damage, we could only find a few samples containing TNF- $\alpha$ $(7 \cdot 9 \%)$ or IL-6 $(10 \cdot 5 \%)$ in our 38 samples of proteins from urine. Noble $e t a l^{8}$ reported that the number of mononuclear cells in glomeruli was well correlated with the amount of urinary protein excretion and the concentrations of IL-1 $\beta$ and TNF- $\alpha$ in urine in experimental proliferative immune complex glomerulonephritis. The inconsistency between our results and other reports is a result of $(a)$ different disease (lupus nephropathy $v$ immune complex glomerulonephritis), (b) different species

Table 4 Pokeweed mitogen (PWM) enhancing activity of fractions III and IV $(40 \mu \mathrm{g} / \mathrm{ml})$ derived from proteins in urine of patients with active and inactive lupus nephritis

\begin{tabular}{|c|c|c|c|c|c|}
\hline & \multirow{2}{*}{$\begin{array}{l}\text { Human IgG } \\
(40 \mu g / m l)\end{array}$} & \multicolumn{2}{|c|}{ Active nephritis } & \multicolumn{2}{|c|}{ Inactive nephritis } \\
\hline & & Fraction III & Fraction $I V$ & $\overline{\text { Fraction III }}$ & Fraction $I V$ \\
\hline $\begin{array}{l}\text { Mean (SEM) PWM enhancing } \\
\text { activity (\%) } \\
\text { p Value* }\end{array}$ & $1 \cdot 2(1 \cdot 3)$ & $\begin{array}{c}10 \cdot 1(7 \cdot 7) \\
0.051\end{array}$ & $\begin{array}{c}85 \cdot 8(10 \cdot 5) \\
0.0004\end{array}$ & $\begin{array}{l}1.7(0.5) \\
0.31\end{array}$ & $\begin{array}{c}58.4(8.9) \\
0.001\end{array}$ \\
\hline
\end{tabular}

${ }^{*}$ Calculated by Wilcoxon signed rank test. 
(human $v$ rat), and (c) a different method, as we determined the cytokine concentration in proteins concentrated to $5 \mathrm{mg} / \mathrm{ml}$ in urine rather than in the original urine sample.

The soluble IL-2 receptor is a cytokine binder released mainly from activated $T$ lymphocytes ${ }^{17}$ and is found at increased concentrations in serum samples from patients with active SLE. ${ }^{18}{ }^{19}$ This soluble peptide is also present in the urine of normal subjects ${ }^{20}$ and its concentration is increased in patients with adult $\mathrm{T}$ cell leukaemia. ${ }^{21}$ In this study, we found that sIL-2R was also increased in the proteins from urine of patients with active lupus nephritis compared with patients with inactive nephropathy or without SLE. However, this increment was not parallel with the concentration in serum and inversely correlated with the 24 hour protein excretion. It appears that sIL-2R in urine may not all come from the circulation through damaged glomeruli. Local production by infiltrating mononuclear or mesangial cells in the inflamed kidney is possible as these cells can actively secrete immune mediators such as IL-1, TNF- $\alpha$, IL-6, TGF- $\beta^{6^{71-16}}$ or eicosanoid metabolites $^{22}$ to exert nephrotoxic effects on renal parenchymal tissue. Werber et $a l^{14}$ and Boswell and coworkers ${ }^{6}$ showed that the renal cortical cells or macrophages from autoimmune MRL/1pr mice with nephritis contained several times more IL- $1 \beta$ and TNF mRNA compared with normal mice. Accordingly, the direct determination of cytokines or related molecules in protein from urine may provide a reliable method of evaluating the severity of lupus nephritis. Although we did not find a significant difference in the IL- 6 and TNF- $\alpha$ concentrations among the three groups, we did note a 23 kilodalton molecule with IL-4 like activity in urine from nephritic and nephrotic patients, but not in urine from patients without SLE. The properties of this pokeweed mitogen enhancing factor were not defined in this study.

Another interesting finding in this study was the presence of free light chain immunoglobulins in six samples of protein from urine from the nephritis group. The concentrations of urinary SIL-2R and serum titres of antibody to dsDNA were also fairly high in these patients. Epstein $^{10}$ and Hopper and coworkers ${ }^{9}{ }^{11}$ clearly showed that the presence of urinary free light chain immunoglobulins preceded clinical exacerbation of SLE. Turnover studies in humans by Waldmann et $a l^{23}$ showed that only $60 \%$ of newly synthesised light chains were eventually incorporated into complete antibody molecules; the remaining $40 \%$ of the light chain immunoglobulins were released into serum and subsequently catabolised in the renal proximal tubules. In the absence of interstitial renal disease, urinary free light chain concentrations might reflect the quantitative degree of in vivo $B$ cell Ig production. ${ }^{10}$ However, for active lupus nephritis, both polyclonal B cell activation and renal tubule impairment may be responsible for the presence of urinary free light chains. The significance of this observation needs further evaluation.

In conclusion, this is the first study to analyse the composition of proteins from urine in human lupus nephropathy. We have found that increased sIL-2R, free light chains, and the presence of cytokine like molecules in protein from urine can directly reflect the severity of inflammatory and immunological reactions in patients with lupus nephritis and may serve as supplemental tests to histological examination of the renal tissue.

This work is supported by grants from the National Science Council and from the Institute of Biomedical Sciences, Academia Sinica, Republic of China. We are indebted to Miss Lina Lin fo her technical assistance and Miss Chun-Shia Chong for typing
this manuscript.

1 Becker G B, Hancock W W, Stow J L, Glasgow E F, Atkins $\mathrm{R} C$, Thomson N M. Involvement of the macrophage in experimental chronic immune complex glomerulonephritis. Nephron 1982; 32: 227-33.

2 Hooke D H, Hancock W W, Gee D C, Kraft N, Atkins R C. Monoclonal antibody analysis of glomerular hypercellularity in human glomerulonephritis. Clin Nephrol 1984; 22: 163-8.

3 Nolasco F E B, Cameron J S, Hartley B, Coelho A, Hildreth G, Reuben R. Intraglomerular T cells and monocytes in nephritis: study with monoclonal antibodies. Kidney Int nephritis: study

4 Lovett D H, Ryan J L, Sterzel R B. A thymocyte-activating factor derived from glomerular mesangial cells. $\mathcal{F}$ Immunol 1983; 130: 1796-801.

5 Lovett D H, Sterzel R B, Ryan J L, Atkins E. Production of an endogenous pyrogen by glomerular mesangial cells. f Immunol 1985; 134: 670-2.

6 Boswell J M, Yui M A, Endres S, Burt D W, Kelley V E Novel and enhanced IL-1 gene expression in autoimmune mice with lupus. F Immunol 1988; 141: 118-24

7 Boswell J M, Yui M A, Burt D W, Kelley V E. Increased tumor necrosis factor and IL-1/, gene expression in the kidneys of mice with lupus nephritis. F Immunol 1988; 141 : $3050-4$.

8 Noble B, Ren K, Taverne J, et al. Mononuclear cells in glomeruli and cytokines in urine reflect the severity of experimental proliferative immune complex glomerulonephritis. Clin Exp Immunol 1990; 80: 281-7.

9 Hopper J E, Papagiannes E. Evidence by radioimmunoassay that mitogen-activated human blood mononuclear cells secrete significant amounts of light chain Ig unassociated with heavy chain. Cell Immunol 1986; 101: 122-31.

10 Epstein W V. Immunologic events preceding clinical exacerbation of systemic lupus erythematosus. $A m \mathcal{F} \mathrm{Med}$ $1973 ; 54: 631-6$.

11 Hopper J E, Sequeira W, Martellotto J, Papagiannes E, Perna L, Skosey J L. Clinical relapse in systemic lupus erythematosus:correlation with antecedent elevation of urinary free light-chain immunoglobulin. 7 Clin Immunol urinary free light-c

12 Seckinger $\mathrm{P}$, Williamson $\mathrm{K}$, Balavoine J-F, et al. A urine inhibitor of interleukin 1 activity affects both interleukin $1 \alpha$ and $1 \beta$ but not tumor necrosis factor $\alpha . \mathcal{F}$ Immunol 1987 139: $1541-5$

13 Seckinger $\mathbf{P}$, Isaaz $S$, Dayer J-M. A human inhibitor of tumor necrosis factor $\alpha . \mathcal{F} \operatorname{Exp} M$ ed 1988; 167: 1511-6.

14 Werber H I, Emancipator S N, Tykocinski M L, Sedor J R. The inter-leukin 1 gene is expressed by rat glomerular mesangial cells and is augmented in immune complex glomerulonephritis. F Immunol 1987; 138: 3207-12.

15 Van Oers M H J, Van Der Heyden A A P A M, Aarden L A. Interleukin 6 (IL-6) in serum and urine of renal transplant recipients. Clin Exp Immunol 1988; 71: 314-9.

16 Okuda S, Languino L R, Ruoslahti E, Border W A. Elevated expression of transforming growth factor- $\beta$ and proteoglycan production in experimental glomerulonephritis glycan production in experimental glomerulonephritis
possible role in expansion of mesangial extracellular matrix. possible role in expansion of mesa

17 Rubin L A, Kurman C C, Fritz M E, et al. Soluble interleukin 2 receptors are released from activated human lymphoid cells in vitro. F Immunol 1985; 135: 3172-7.

18 Wolf R E, Brelsford W G. Soluble interleukin-2 receptors in systemic lupus erythematosus. Arthritis Rheum 1988; 31: 729-35.

19 Tokano Y, Murashima A, Takasaki Y, Hashimoto H, Okumura $\mathrm{K}$, Hirose $S$. Relation between soluble interleukin 2 receptor and clinical findings in patients with
systemic lupus erythematosus. Ann Rheum Dis 1989; 48: 803-9.

20 Novick D, Engelmann H, Wallach D, Rubinstein M. Soluble cytokine receptors are present in normal human urine. cytokine receptors are presen
fExp Med 1989; 170: $1409-14$.

21 Marcon L, Fritz M E, Kurman C C, Jensen J C, Nelson D L Soluble Tac peptide is present in the urine of normal Soluble Tac peptide is present in the urine of normal
individuals and at elevated levels in patients with adult individuals and at elevated levels in patients with adult
$T$ cell leukaemia (ATL). Clin Exp Immunol 1988; 73: 29-33.

22 Stahl R A K, Thaiss F, Kahf S, Schoeppe W, Helmchen U M Immune-mediated mesangial cell injury-biosynthesis and Immune-mediated mesangial cell injury-biosynthes

23 Waldmann T A, Strober W, Mogielnicki R P. The renal aldmann T A, Strober W, Mogielnicki R P. The renal
handling of low molecular weight proteins. II. Disorders of serum protein catabolism in patients with tubula proteinuria, the nephrotic syndrome, or uremia. $\mathcal{J}$ Clin Invest 1972; 51: 2162-74. 